\title{
Ikonisitas Tata Panggung: Sebuah Kajian Semiotika Seni Rupa Teater
}

\author{
UNTUNG TRI BUDI ANTONO* \\ Jurusan Teater, Fakultas Seni Pertunjukan, Institut Seni Indonesia Yogyakarta
}

\begin{abstract}
The Semiotic of Stage. Semiotics is a study dealing with signs and sign systems. Signs are created for the needs of communication and information. According to Piercean's, semiotics in theatre is a transformation of story signs which symbolically become iconic signs of its acts. Stage setting is an artistic part of theatre which makes use the potentials of iconicity. Since its functions as a drama support of the acts, its potentials of iconicity optimize its functions.
\end{abstract}

Key words: iconisity, stage, transformation

\section{Pendahuluan}

Berkarya seni drama adalah mentransformasikan cerita hasil karya sastra menjadi lakon seni pertunjukan drama. Dalam transformasi ini muncul elemen artistik yang merupakan segala faktor yang meliputi dan melatari atau melingkungi cerita dalam naskah. Elemen artistik meliputi tata pentas atau tata panggung, tata cahaya, tata rias, tata busana dan tata bunyi sebagai hasil perubahan potensi simbol dalam naskah cerita menjadi potensi ikon dalam pementasan drama.

Secara semiosis, tata panggung adalah transformasi tanda ruang, waktu dan suasana sastrawi yang simbolis menjadi tanda ruang, waktu dan suasana rupa yang dalam pembahasan ini memanfaatkan potensi ikonisitas, agar menghasilkan tata panggung yang sesuai dengan tuntutan cerita, representatif dan mendukung dramatika peristiwa lakon.

\section{Pengertian Semiotika}

Semiotika yang secara etimologis berasal dari kata Yunani semeion yang berarti "tanda" (Nöth, 1990: 57) sudah terdapat di sekitar kehidupan kita, bahkan sudah kita buat sejak dahulu, seperti gerak, suara, rupa, dan lain-lain. Gerak, suara dan rupa karya seni adalah unsur-unsur yang tidak berdiri sendiri dan kompleks. Dengan demikian integrasi dan kompleksitas karya seni bisa disebut sebagai sistem tanda atau tanda mayor yang terdiri dari tanda-tanda minor. Oleh sebab itu semiotika bisa diartikan sebagai ilmu tentang tanda dan sistem tanda. Menurut Pierce tanda adalah "something which stands to somebody for something in some respects or capacity" (Eco, 1976: 15). Tandatanda ini membuat kita berpikir, berkomunikasi dan memberi makna pada segala sesuatu yang perceptible dengan mengembangkan perhatiannya pada fungsi tanda secara umum.

Menurut Pierce tanda mengacu atau mempresentasikan objek. Tanda dapat berfungsi apabila ada ground (dasar, landasan) yang menjadi liputannya. Misalnya tanda rambu lalulintas, yang menjadi groundnya adalah pemahaman tentang sistem rambu-rambu lalulintas. Tanda yang juga disebut representamen mempunyai relasi dengan objek dan dimaknai oleh interpretan. Hubungan antara representamen, objek dan interpretan disebut hubungan triadik atau segitiga semiotika sebagai proses simiosis.

Pada umumnya tanda bersifat transindividual yang dapat dipahami orang banyak, namun demikian ada juga tanda yang bersifat individual yang baru bisa berfungsi apabila ada interpretan (Nöth, 1990: 42). Menurut Pierce hubungan

\footnotetext{
* Alamat korespondensi: Jln. Parangtritis KM. 6,5 Sewon, Yogyakarta. Tlp. 0274-375380, Kotak Pos 1284 Yogyakarta 55001. HP: 0818276569. e-mail: untungtba@gmail.com
} 
antara tanda dengan acuannya dibedakan menjadi tiga yaitu ikon, indeks dan simbol (Nöth, 1990: 42-43). Pada ikon, tanda diartikan menurut hubungan kemiripan antara tanda itu dengan yang diwakilinya. Pada indeks, tanda diartikan menurut hubungan keterkaitan atau sebab akibat atau indikasi. Pada simbol, tanda diartikan menurut kesepakatan atau konvensi yang dibentuk secara bersama-sama oleh masyarakat tempat simbol itu berlaku.

Dari uraian di atas ada hal yang bisa dipahami, yaitu bahwa sebuah tanda dapat mengandung arti sekaligus mengundang reaksi yang bermacammacam. Suatu tanda dapat mempunyai banyak arti bagi segolongan orang atau individu, namun bisa tidak berarti sama sekali bagi golongan atau individu yang lain. Tidak jarang terjadi polemik yang diakibatkan kehadiran sebuah tanda, misalnya gambar bintang di lantai di tempat umum yang dibentuk dari keramik; sebuah patung atau lukisan wanita telanjang; dan sebagainya yang kemudian mengundang reaksi pro-kontra karena persoalan penafsiran yang tidak sama mengenai arti atau maksud tanda tersebut diantara masingmasing orang yang menerima tanda itu. Di sekitar kita banyak dijumpai tanda sebagai alat komunikasi yang efektif, namun sebaliknya tidak jarang pula kita jumpai berbagai ekses buruk yang ditimbulkan oleh sebuah tanda, misalnya atributatribut keagamaan, lambang-lambang partai, poster-poster dan sebagainya.

Salah satu faktor penyebab terjadinya tanggapan yang berbeda-beda di antara masingmasing orang terhadap sebuah tanda adalah adanya interpretasi atau pengartian yang berbeda dipengaruhi oleh acuannya sendiri-sendiri atas dasar latar belakang pengalaman kecenderungan yang tidak sama, dan berpengaruh terhadap keputusan pengambilan kesimpulan mengenai arti tanda. Gambar tokoh politik yang sedang tersenyum tentu mempunyai makna yang berbeda di antara pendukung dan lawan politiknya. Dalam proses-proses semiosis yang terjadi di antara tanda-tanda dan sistem tanda dapat menstimulasi asosiasi pengamat secara denotatif dan konotatif. Secara denotatif senyuman tokoh politik pada gambar hanya dilihat sebagai sesuatu yang tidak indah bagi lawan politiknya, sedangkan secara konotatif bisa diartikan sebagai ejekan.
Dari paparan di atas ada dua hal yang perlu diperhatikan dalam membaca tanda yaitu: (1) Sinkronisasi tanda dan sistem tanda secara spasial dan temporal; (2) Ground mapping secara spasial dan temporal.

Dua hal di atas saling terkait karena memahami latar belakang berbagai faktor yang memotivasi munculnya tanda-tanda tidak terlepas dari faktor filosofi dan spirit terjadinya tanda-tanda itu. Hal itu penting karena representamen yang sama bisa berbeda interpretan dan objeknya karena ruang dan waktu yang berbeda. Sebuah foto pemandangan di luar negeri yang kita tidak tahu di mana, sangat sulit untuk mengetahui objek di dalam foto itu pagi hari, siang hari atau sore hari. Objek yang sama bisa berbeda interpretan dan representamen. Lukisan Abad Pertengahan Madonna and Child tampak berbeda gaya dan ekspresi atau paham kerupaannya dengan lukisan Virgin and Child pada era Renaisans.

Pada proses-proses semiosis yang sama bisa dilandasi ground yang berbeda. Gambar bintang mempunyai makna simbolik yang berbeda di kalangan keagamaan dan kemiliteran, dan merupakan metafor sebagai istilah di kalangan perfilman dan olahraga. Gambar atau patung ular mempunyai makna simbolik yang berbedabeda pada banyak kebudayaan dan kepercayaan. Dengan demikian ground bisa diartikan konteks, sedangkan proses semiosis adalah teks. Oleh sebab itu menganalisa tanda-tanda dan sistem tanda harus paham betul groundnya secara sinkronik sehingga analisis itu tidak dangkal, sempit dan jauh menyimpang.

\section{Semiotika dan Tata Panggung}

Semua mode pada dasarnya akan dinyatakan dalam suatu proses simbolis atau sistem tandatanda walaupun itu interpersonal atau sosial (Jakobson dalam Hawkes, 1997: 79-80). Bentuk struktur dan unsur-unsur skeneri atau tata pentas drama sejak zaman Yunani kuno, kemudian berkembang dengan tahapan-tahapan teknis hingga kini, dan variasi-variasi yang terjadi pada penyebaran dan turun-temurunnya yang menimbulkan berbagai karakteristik dan gaya, kesemuanya itu adalah mode, yaitu suatu cara mengekspresikan dan mengkomunikasikan pesan, gagasan, pemikiran, ajaran, keyakinan, 
pandangan dan perasaan perancang tata panggung berdasarkan pada tuntutan naskah lakonnya, yang memegang peran dalam penciptaan tata panggung. Bentuk tata panggung sebagai media ekspresi dan komunikasi dalam rangka mendukung dramatika peristiwa lakon, akan berfungsi apabila mengacu kepada objek yang dikenal dan dipahami oleh masyarakat penontonnya. Dengan demikian bentuk tata panggung adalah sistem tanda yang menggambarkan struktur objek yang dikenal dan dipahami masyarakat penontonnya, dan diformasikan secara representatif untuk mengisyaratkan suatu kode latar ruang, waktu dan suasana peristiwa lakon yang dicitrakan dalam naskah.

Tanda atau representamen adalah sesuatu yang menggantikan sesuatu dalam beberapa hal atau kapasitas bagi seseorang. Tanda ini tertuju kepada seseorang, artinya menciptakan tanda lain yang setara atau barangkali yang lebih berkembang di dalam pikiran orang tersebut. Tanda yang tercipta itu disebut interpretant bagi tanda pertama. Tanda itu ringkasan dari sesuatu, yaitu objeknya. Ini berarti bahwa tidak semua hal dari objek itu diacu atau digantikan, tetapi hanya berkenaan pada satu macam ide saja (Peirce dalam Nöth, 1990: 42). Sebagaimana akan terlihat, tanda dapat berlaku sebagai sesuatu yang lain bagi seseorang hanya karena relasi keberadaannya ditengahi oleh interpretant (Eco, 1976: 15).

Pada trikotomi tanda kedua, yang mengklasifikasikan tanda berdasarkan pada hubungan dengan acuan atau objeknya, Peirce membagi tanda yang terdiri dari ikon (kepertamaan), indeks (kekeduaan) dan simbol (keketigaan) (Nöth, 1990: 44). Ikon adalah tanda yang dengan acuannya memiliki hubungan kemiripan. Indeks adalah tanda yang dengan acuannya mempunyai kedekatan eksistensial atau hubungan kausal. Sedangkan simbol merupakan tanda yang dalam hubungan dengan acuannya telah terbentuk secara konvensional (Budiman, 2005: 56-59). Dalam semiotika Peircean, ikonisitas adalah salah satu dari tiga relasi tanda tersebut, relasi suatu representamen yang menggantikan objek referensinya. Relasi itu tidak bisa terlepas dari ground (latar) yang menjadi konteksnya. Ikonisitas sebagai jenis pertama dari relasi-relasi tanda merupakan gagasan mengenai sesuatu seperti adanya tanpa mempedulikan hal-hal lain. Namun demikian ikonisitas dipa- hami dengan sangat longgar dan variatif yaitu sebagai similaritas, kesamaan, kepersisan, keserupaan, kemiripan, keidentikan sampai dengan asosiasi atau perhubungan (Budiman, 2005: 149). Dinyatakan oleh Peirce bahwa ikon murni sesungguhnya tidak ada (Sonesson dalam Budiman, 2005: 151). Ikonisitas selalu tercakup dalam indeksitas atau simbolitas (Sudjiman dan Zoest, 1996: 10). Naskah cerita sebagai karya sastra, dari pandangan semiotika Peircean adalah susunan tanda-tanda simbolis karena bahasa merupakan sistem tanda konvensional. Namun demikian di balik simbolitasnya itu, naskah cerita hasil karya sastra juga mampu memanfaatkan dimensi-dimensi ketandaan ikonis dan indeksis (Budiman, 2005: 95).

Pada naskah cerita yang merupakan sistem tanda simbolis, di dalamnya terdapat larik-larik kalimat yang memiliki dimensi ikonis. Lariklarik kalimat ikonis itu ada yang mengisyaratkan berbagai unsur ruang, waktu dan suasana. Tipe ikonis masing-masing larik kalimat bisa berbeda satu sama lain tergantung gaya kalimatnya. Tipetipe ikonis yang bisa ditemukan dari hasil analisis naskah cerita, sesuai dengan penelitian ini ialah: ikon imagis, berdasarkan pada similaritas citrawi, antara representamen dan objeknya memiliki keserupaan atau maksud yang sama; ikon metaforis, berdasarkan pada similaritas asosiasi, antara representamen dan objeknya memiliki analogi sifat; ikon indeksis, berdasarkan pada similaritas eksistensial, antara representamen dan objeknya memiliki hubungan kausalitas; ikon simbolis, berdasarkan pada similaritas makna, antara representamen dan objeknya memiliki hubungan konvensionalitas; dan ikon metonimis, berdasarkan pada similaritas presentasi, antara representamen dan objeknya memiliki hubungan representatif.

Semiotika memperhatikan segala sesuatu yang dapat diterima sebagai tanda. Tanda adalah segala sesuatu yang dapat diterima sebagai pengganti sesuatu yang lain secara signifikan (Eco, 1976: 7). Larik-larik kalimat ikonis dalam naskah cerita adalah menggantikan segala sesuatu yang ditandakan dan ada dalam kehidupan nyata atau dalam angan-angan penulisnya. Segala sesuatu yang ditandakan dengan larik-larik kalimat tentu akan mengalami seleksi dan dramatisasi tahap pertama pada naskah cerita. Tata panggung yang 
juga ikonis akan menggantikan larik-larik kalimat ikonis yang mengisyaratkan ruang, waktu dan suasana dalam naskah ketika cerita didramakan. Dalam proses pendramaan ini tanda ikonis ruang, waktu dan suasana akan mengalami seleksi dan dramatisasi tahap kedua. Dengan demikian signifikansi penggantian unsur ruang, waktu dan suasana di sini terjadi dua kali, yaitu pada seleksi dan dramatisasi tahap pertama dan kedua.

Maksud analisis semiotika terhadap pengetahuan mengenai struktur organisasi hasilhasil karya adalah beberapa reaksi, evaluasi atau interpretasi dari penonton yang mereka tambahkan secara bebas ketika menggambarkan yang kadangkadang memberi kontribusi pada dimensi semantik, yaitu makna tanda (Saint-Martin, 1990: 192). Naskah-naskah cerita drama akan memberi imaji ruang, waktu dan suasana sebagai latar peristiwa lakon bagi pembaca, khususnya penata pentas. Imaji ini akan berbeda-beda pada setiap pembaca, yang akan menimbulkan interpretasi yang berbeda-beda pula. Dengan demikian setiap naskah cerita yang didramakan berkali-kali akan terjadi variasi dalam pementasannya, termasuk tata panggungnya. Dalam hal ini setiap penata panggung memiliki kebebasan kompromis dengan sutradara untuk mendramatisasi unsur ruang, waktu dan suasana demi menegaskan dan memperkuat dramatika peristiwa lakon sebagai intensifikasi pengungkapan makna.

\section{Ikonisitas}

Dalam semiotika Peircean, ikonitas adalah salah satu dari tiga relasi tanda, relasi suatu representamen yang menggantikan suatu objek referensinya. Relasi itu tidak bisa terlepas dari ground, latar yang menjadi konteksnya. Ikonisitas sebagai jenis pertama dari relasi-relasi tanda merupakan gagasan mengenai sesuatu seperti adanya tanpa mempedulikan hal-hal yang lain. Namun demikian ikonisitas dipahami dengan sangat longgar dan variatif yaitu sebagai similaritas, kesamaan, kepersisan, keserupaan, kemiripan, keidentikan sampai dengan asosiasi/perhubungan. Oleh sebab itu bangunan joglo bisa menjadi ikon Jawa, teddy bear menjadi ikon Presiden Amerika Serikat, Theodore Roosevelt, dan sebagainya.

Pure icon, ikon murni sesungguhnya tidak ada (Peirce dalam Sonesson dalam Budiman, 2005:
151). Ikonisitas selalu tercakup dalam indeksitas atau simbolitas (Sudjiman dan Zoest, 1996: 10). Pada ikonisitas asosiasi yang barangkali bisa dikira murni, tetap tidak murni, misalnya seekor kerbau dibandingkan dengan seorang yang bodoh, kawanan bebek diasosiasikan dengan orang-orang yang bisanya cuma ikut-ikutan. Seekor kerbau dan kawanan bebek adalah tanda ikonis, atau kadang disebut hipo-ikon oleh Peirce (Sonesson dalam Budiman, 2005: 152). Dengan demikian 'kebodohan' seekor kerbau dan 'sifat mengekor' kawanan bebek barangkali dapat dianggap ikonisitas. Dalam hal ini ikonisitas boleh dikatakan ada namun tidak eksis sampai suatu perbandingan dilakukan. Seekor kerbau dan kawanan bebek bukan ikon sampai ketika dibandingkan dengan orang bodoh dan manusia-manusia pengekor.

Dua faktor ikonisitas, representamen dan denotatum (objek) yang ditetapkan sebagai mana adanya, maka standar perbandingannya harus merupakan suatu similaritas, suatu tanda yang menggantikan sesuatu semata-mata karena serupa; atau identitas, yaitu mengambil bagian pada karakter/sifat objek, maksudnya ada persamaan sifat yang menggejala. Sesuai dengan prinsip ini, maka ikonisitas adalah semata-mata perihal kadar, derajat, atau intensitas similaritasnya. Samasama menandakan bahaya maut di jalan, sebuah monumen mobil yang ringsek kadar ikonisitasnya lebih tinggi dibanding gambar tengkorak dengan dua tulang disilangkan.

Persepsi dan visi sangat menentukan dalam mengidentifikasikan sebuah ikon. Similaritas dan identitas yang dimiliki sebuah ikon dengan jelas akan menghasilkan kadar tertinggi ikonisitas. Sebuah gambar lingkaran yang dibentuk dengan garis hitam yang hanya memiliki similaritas sangat mungkin menimbulkan persepsi dan visi yang berbeda-beda bagi setiap orang. Namun apabila di sekeliling lingkaran itu diberi garis-garis memancar sebagai identitas, maka sebagian besar orang akan menganggap lingkaran bergaris memancar itu menggantikan matahari pada tataran ikonis.

Konvensi adalah faktor yang menentukan pula bahwa sesuatu akan bisa menjadi tanda. Secara konvensional semua orang tahu bahwa closet dipasang di kamar kecil, tetapi apabila tibatiba dipasang pada meja makan di ruang pameran seni rupa kontemporer, pastilah itu dimaksudkan 
sebagai tanda. Secara konvensional semua orang tahu kalau tiang itu selalu berdiri tegak, namun apabila pada tata panggung ada tiang yang dipasang miring, tentu kemiringan itu suatu tanda. Secara konvensional semua orang tahu bahwa tertawa adalah tanda kegembiraan, apabila di dalam sebuah filem ada seorang aktor yang tibatiba tertawa terbahak-bahak, bisa diduga tawa itu suatu tanda, apalagi ketika dia dalam adegan itu justru sedang mengalami kesedihan. Dengan konvensi, closet pada meja makan, tiang miring di panggung dan tawa aktor yang sedang gembira atau sedih adalah suatu ikonisitas. Closet pada meja makan adalah ikon metaforis, tiang miring di panggung adalah ikon indeksis atau metaforis dan tawa aktor adalah ikon indeksis, tawa karena gembira atau tawa karena hysterics.

\section{Semiotika Seni Rupa Teater}

Dalam seni visual atau seni rupa dikenal unsurunsur fisioplastis yang terdiri dari titik, garis, bidang, ruang, bentuk, barik dan warna. Psikoplastis atau prinsip komposisi yaitu kesatuan harmonis yang unsur-unsurnya terdiri dari: kontras, irama, klimaks, keseimbangan dan proporsi, kemudian Ideoplastis atau ekspresi yang bermacam-macam. Semua unsur itu hanya merupakan abstraksi dari unsurunsur yang ada di setiap karya seni rupa sebagai tanda dan sistem tanda. Dalam seni rupa teater persoalannya menjadi semakin rumit lagi, karena seni rupa di sini menjadi tanda, sistem tanda dan fungsi tanda atau penandaan yang berhubungan dan menandai ruang, waktu dan suasana yang dikomunikasikan. Sebenarnya setiap unsur rupa sebagai sekedar sign atau unsur estetik maupun artistik sudah memiliki konteksnya sendiri-sendiri yang mengacu kepada objek yang dilambangkan atau disimbolkan dan direpresentasikan. Kata tone dan texture dalam seni rupa misalnya tentu berbeda artinya ketika digunakan pada seni yang lain. Warna pada lukisan realis tentu mempunyai konteks yang berbeda dengan warna pada lukisan non realis, setting panggung drama realis tentu berbeda dengan setting drama non realis. Itu semua sudah menjadi konvensi sistem tanda sejak lama.

Ikon dalam seni rupa dan seni rupa teater bisa dilihat antara lain pada seni rupa realis dan tata artistik realis tempat penandaan dan acuan mempunyai kemiripan rupa. Indeks bisa dilihat antara lain pada karya seni Abad Pertengahan yang 'suram' mengesankan suasana religius. Sedangkan simbol antara lain pada penggunaan warna secara heraldis, simbol garis ekspresi dan sebagainya.

Sebenarnya kalau boleh disimpulkan, para semiolog adalah orang-orang yang berinisiatif untuk "mengumpulkan" tanda-tanda dan sistem tanda yang "berserakan" ke dalam suatu ruang lingkup pengetahuan ilmu yang disebut semiotika atau semiologi. Namun ketika disadari bahwa tanda dan sistem tanda pada setiap objek acuan yang sangat banyak itu beragam dan berbeda-beda satu sama lain, maka memungkinkan di dalam dunia kesenian muncul semiotika-semiotika yang menjurus ke masing-masing bidang seni antara lain semiotika seni rupa, semiotika teater, semiotika musik dan sebagainya.

\section{Ikonisitas Seni Rupa Teater}

Berbeda dengan karya sastra pada naskah dan dialog teater yang merupakan seni bahasa yang bersifat simbol, karya seni visual atau seni rupa teater lebih banyak menggunakan tanda-tanda ikonis daripada simbolis. Apabila menyandang unsur simbolis, tanda itu sebagian besar tetap ikon karena konvensi yang memunculkan simbol selalu mengacu kepada sifat-sifat yang dimiliki oleh objek yang disimbolkan, meskipun sifatsifat itu tidak selalu riil. Tanda simbol bintang yang dimaknai ketuhanan disebabkan, bintang berada di langit. Tanda simbol bintang yang dimaknai sebagai kemasyhuran karena bintang bersinar terang berkilauan menerangi langit malam. Titik, garis, bidang, ruang, bentuk, warna, tekstur, komposisi, kinetiks dan unsurunsur visual lainnya yang ada dalam tata visual teater bekerja sama membentuk gugusan ikon yang memberi arti skene (ruang, waktu, suasana dan peran). Hal ini terutama terjadi secara wantah pada karya-karya teater realistis. Pada karya-karya teater non realistis dan absurd ikonisitas memang tidak mudah terbaca, namun bukan berarti bukan ikon, tetapi objek yang menjadi acuannya samarsamar atau tidak kasat mata. Antara yang realistis dan nonrealistis hanya berbeda pada intensity of iconicity dari tanda-tanda yang ditampilkan. Oleh sebab itu, sesuai dengan substansinya, karya tata visual/rupa teater pada prinsip dasarnya adalah ikonis. 
Pada seni rupa teater ikonisitas digunakan sebagai pengkajian semiotika, karena ikon adalah tanda yang didasarkan pada "keserupaan" atau "kemiripan" di antara representamen dan objeknya, apakah objek itu eksis atau tidak.

Tanda adalah sesuatu yang menunjukkan kepada seseorang bagi sesuatu dalam beberapa hal atau kapasitas (Peirce dalam Eco, 1979: 15), ikon defined by the criterion of similarity between sign (representamen) and object (Nöth, 1990: 122).

Unsur-unsur visual pada seni rupa teater membentuk suatu kesatuan sebagai gugusan ikon yang tampak sebagai skeneri, properti, pencahayaan, busana, rias dan sebagainya. Pada seni rupa teater yang realistik tampak jelas gejala ikonisitasnya dibanding pada seni rupa teater non realistik; yang juga dibedakan oleh derajat ikonisitasnya. Oleh sebab itu seni rupa teater bisa disebut sebagai salah satu ikonis.

Sebuah penataan panggung dan pameran biasanya hanya dilihat sebagai pelengkap totalitas dramatik peristiwa lakon. Namun apabila diamati secara lebih kritis proses-proses semiosis yang terjadi di antara tanda-tanda dan sistem tanda yang ada di dalamnya akan menstimulasi asosiasi penonton kepada suatu makna yang lebih luas dan dalam. Persoalannya adalah apakah penonton mampu membaca tanda-tanda dan sistem tanda itu atau tidak. Di antara yang mampu akan terjadi interpretasi imagis dan metaforis yang berbedabeda sesuai dengan latar belakang masing-masing penonton, dan itu bisa berbeda dengan kehendak penulis naskah dan sutradara. Kemudian indeks dan simbol yang ada juga bisa menimbulkan interpretasi imagis dan metaforis yang berbedabeda pula antara penonton.

Pada penjelasan berikut akan dianalisis ikonisitas dua tata panggung teater, yaitu tata panggung teater Abad Pertengahan yang khas dengan tanda-tanda kekristenannya dan tata panggung Renaisans Serlian yang merupakan pengembangan dari tata panggung teater klasik Yunani kuno dan Roman. Masing-masing tanda panggung itu dilatari oleh spirit yang sangat berbeda.

\section{Ikonisitas Tata Panggung Teater Abad Pertengahan}

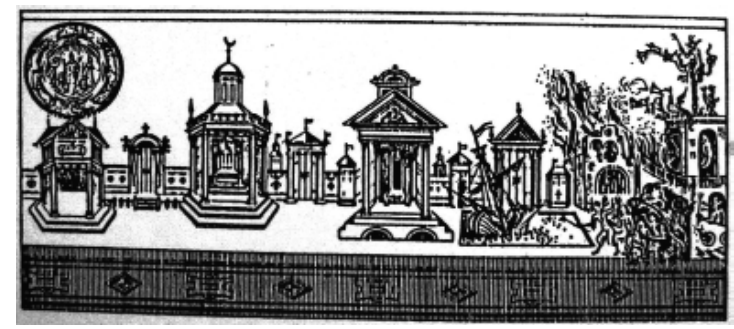

Gambar di atas adalah sketsa yang menunjukkan panggung teater Abad Pertengahan. Sebagai panggung drama liturgi Kristen, maka penataannya merupakan representasi dari ruang dan waktu yang diriwayatkan dalam Bible. Secara denotatif yang tampak pada gambar itu hanyalah deretan bangunan-bangunan dan wujud miniatur yang objeknya dibenarkan atau disungguhkan besar dan megah. Namun demikian apabila kita tahu apa yang diriwayatkan dalam Bible, maka kita akan melihat bahwa deretan itu adalah tandatanda ikonik dari heaven, hell, and limbo, and such earthly locales as Pilate's house, the palace of Herod, the temple of Jerusalem, and stable in Bethlehem (Macgowan, Melnitz, 1965: 57) sebagai skeneri latar belakang peristiwa lakon. Ikon-ikon yang disebut mansion atau house itu merepresentasikan ruang-ruang dan waktu-waktu sebagai objek yang sangat besar dan lama. Pada representamen gambar bangunan paling kiri tampak tidak hanya sebuah ikon imagis simbolis karena bentuk itu menggambarkan surga yang ditandai dengan bulatan di atasnya. Demikian juga representamen paling kanan yang menggambarkan neraka, sangat mungkin juga simbolis. Persoalannya adalah orang pada umumnya memahami api neraka secara denotatif, bahwa imaji tentang api neraka adalah seperti api yang kita lihat sehari-hari; tetapi bukan tidak mungkin bahwa ada sebagian orang yang memahami api neraka secara konotatif, sehingga penggambaran api menjadi ikon simbolis metaforis yang tidak transindividual. Rumah Pilatus, istana Herodes, adalah ikon indeksis yang menunjukkan status sosial dan kekuasaan penghuni dan pemiliknya sebagai tokoh yang diperankan. Bangunan nomor dua dari kiri juga merupakan ikon indeksis bagi konteks spasial dan temporalnya karena arsitekturnya bergaya Bizantine yang menunjukkan Romawi Timur pada abad ke-5 
sampai ke-15. Demikian juga bangunan nomor tiga dari kiri sebagai ikon indeksis bagi konteks spasial dan temporalnya merepresentasikan istana Hirodes yang menunjukkan Yunani Kuno atau Romawi sekitar awal Masehi.

\section{Ikonisitas Panggung Renesans Serlian}

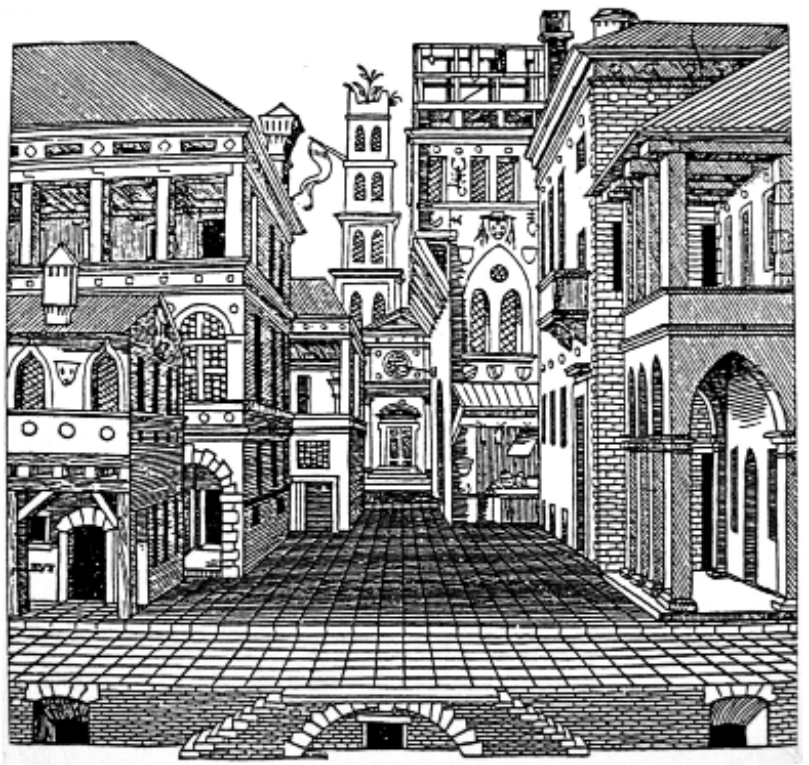

Gambar di atas adalah sket salah satu skene klasik rancangan Sebastiano Serlio (1475-1554) untuk latar belakang drama komedi. Sebagai skene klasik, artinya sebuah rancangan modern yang dibuat untuk memunculkan kembali spirit klasik tentu akan sarat dengan ikon, indeks dan simbol. Dalam bukunya Architettura (1545) Serlio telah memadukan konsep arsitektural Vitruvius (abad 1 SM) dengan konsep perspektif (Renesans). Kedua konsep itu adalah sistem tanda yang terdiri dari gugusan tanda-tanda yang terstruktur. Dalam gambar itu tampak the street with shops and homes yang merupakan tipe penataan panggung untuk drama komedi.

Vitruvius telah meletakkan skenengebaude atau the stage house dengan sisi depan frontal pada panggung teater Yunani Kuno, yang diremodeling Romawi dengan sebutan scaenae frons. Skenengebaude atau sebut saja skene, adalah ikon imagis indeksis. Skene ini merupakan sebuah bangunan yang mengutamakan sisi depannya sebagai latar belakang panggung yang berupa dan berbentuk istana atau kastil. Drama yang dipentaskan hanya tragedi, yaitu cerita atau lakon di seputar kehidupan raja dan para bangsawan yang selalu berakhir dengan sad ending. Wajah skene persis dengan wajah istana yang sesungguhnya, bahkan pada scaenae frons dibuat sangat mewah dan megah. Skene ini jelas menggambarkan bangunan yang penghuninya adalah golongan yang sedang diperankan di hadapannya.

Perspektif telah memberi kontribusi yang sangat signifikan pada Vitruviusisme, sehingga skene menjadi tampak meruang dan sophisticated. Perspektif rekayasa ilusif pada gambar adalah ikon imagis yang terbentuk oleh gugusan tandatanda yang disusun secara konvergenistik sehingga mewujudkan citra sebagaimana mata melihat. Unsur-unsur skeneri adalah ikon indeksis bagi konteks spasial dan temporalnya. Gothic arch pada bagian atas di antara pilar dan bagian atas lubang pintu dan Greek pillar adalah indeks ruang dan waktu di Eropa sekitar awal Masehi. Shops and homes menunjukkan golongan masyarakat apa yang masuk dan ada di dalamnya, karena drama komedi membawakan lakon sekitar kehidupan golongan masyarakat kelas menengah ke bawah yang selalu berakhir dengan happy ending.

Pada umumnya tata panggung drama merupakan gugusan tanda sebagai mode (menurut Roman Jakobson) yang bersifat metonimia. Pada panggung teater Abad Pertengahan mansions atau houses mewakili keseluruhan tempat kejadian dalam Bible, meskipun tempat kejadian yang sesungguhnya pada zamannya tidak diketahui secara persis. Pada panggung Serlian, skeneri merupakan cropping dari lingkungan atau latar tempat terjadinya peristiwa lakon, dengan demikian juga sebagai gugusan ikon metonimis.

\section{Penutup}

Ikonisitas tata panggung teater merupakan sistem semiosis dalam semiotika yang bisa dimanfaatkan untuk menginterpretasikan latar ruang, waktu dan suasana dalam naskah cerita, dan ditransformasikan menjadi tata panggung sebagai latar ruang, waktu dan suasana yang mendukung dramatika permainan drama. Dengan demikian tata panggung bukan lagi hanya sekedar sebagai tempat dan lingkungan permainan, tetapi 
sebagai bagian dari dramatika permainan dengan merekayasa unsur-unsurnya yang memanfaatkan potensi ikonisitas.

\section{Kepustakaan}

Budiman, Kris. 2005. Ikonisitas, Semiotika Sastra, dan Seni Visual, Penerbit Buku Baik, Yogyakarta

Eco, Umberto. 1976. A Theory Semioties, Indiana University Press, Bloomington.

Hawkes, Terence. 1997. Structuralism and Semiotics, Methuen \& Co. Ltd., London.
Macgowan, Kenneth; Melnitz, William. 1965. The Living Stage, A History of the World Theater. N.J: Prentice-Hall, Inc.

Nöth, Winfried. 1990. Handbook of Semioties, Indiana University Press, Indianapolis.

Sahid. Nur. 2004. Semiotika Teater. Yogyakarta: Lembaga Penelitian ISI Yogyakarta.

Saint-Martin, Fernande. 1990. Semiotics of Visual Language. Bloomington: Indiana University Press.

Sudjiman, Panuti; Zoest, Aart van. 1996. Serba-serbi Semiotika. Jakarta: Gramedia Pustaka Utama. 